\title{
THE ROLE OF ZAKAT COMMUNITY DEVELOPMENT BY BAZNAS LAMPUNG IN EMPOWERING COMMUNITIES THROUGH ALTERNATING LIVESTOCK PROGRAM (STUDY ON CENTRAL LAMPUNG REGENCY)
}

\author{
Ghina Ulfah Sachfurrohman ${ }^{1}$, Evi Ekawati ${ }^{2}$, Nur Rachmad Sukowicaksono ${ }^{3}$, Ulul Azmi \\ Mustofa $^{4}$, Suharto ${ }^{5}$ \\ ${ }^{1,2,3,4 \& 5}$ Fakultas Ekonomi dan Bisnis, Universitas Islam Negeri Raden Intan Lampung \\ Email:ghina1223@gmail.com,evi.ekawati@radenintan.ac.id,nsukowicaksono@gmail.com, \\ ululazmimsi@gmail.com,prof.suharto@radenintan.ac.id
}

\begin{abstract}
ABSTRAK
Zakat yang disalurkan ke mustahik (yang berhak atas zakat) akan mempengaruhi ekonomi mereka jika penyalurannya hanya fokus pada usaha produktif. Pada penelitian ini, para peneliti ingin mengetahui seberapa besar peranan Zakat Community Development (ZCD/Pengembangan Masyarakat melalui Zakat) melalui penyediaan program ternak bergilir yang digalakkan oleh BAZNAZ (Badan Amil Zakat Nasional) Lampung untuk memberdayakan masyarakat. Penelitian ini merupakan studi lapangan dengan menggunakan metode campuran atau kombinasi dari metode kualitatif dan kuantitatif. Teknik pengumpulan data yang digunakan yaitu observasi, wawancara, dan dokumen pendukung. Terdapat 27 responden sebagai populasi penelitian dan sampel pada penelitian ini terdiri atas 27 responden juga atau seluruh populasi pada penelitian ini. Berdasarkan hasil analisis, didapatkan tingkat signifikan sebesar 0,105 atau >0,05. Maka dapat diartikan bahwa peran ZCD tidak mempengaruhi pemberdayaan masyarakat dikarenakan kurangnya pengawasan, kontrol, dan evaluasi dari BAZNAZ Lampung melalui program ternak bergilir. Hal ini bertentangan dengan harapan yang menyatakan bahwa penyediaan modal dapat meningkatkan kesejahteraan masyarakat dan mengubah mustahik menjadi muzakki (orang yang wajib membayar zakat).
\end{abstract}

Kata kunci : Pengembangan Masyarakat melalui Zakat, Pemberdayaan Masyarakat, BAZNAZ.

\begin{abstract}
Zakat distributed to mustahik (those entitled to zakat) will affect their economy if the distribution is mainly focused on productive business. In this study, the researchers wanted to know the extent of the role of Zakat Community Development (ZCD) through the provision of alternating livestock programs promoted by BAZNAZ (The National Board of Zakat) Lampung to empower the community. This research is a field study by employing a mixed-method or a combination of qualitative and quantitative methods. The data collection techniques employed were observations, interviews, questionnaires, and supporting documents. There were 27 respondents as the population and sample of this study consisted of 27 respondents as well or the entire population in this study. Based on the results of the analysis, a significant value of $0.105>0.05$ was obtained. Then, it can be interpreted that the role of ZCD has not affected community empowerment due to the lack of supervision, control, and evaluation of the BAZNAZ Lampung through the revolving livestock program. This is in contrast to the expectation that the provision of capital can improve the welfare of the community and turn mustahik into muzakki (those who obliges to pay zakat).
\end{abstract}

Keywords : Zakat Community Development, Community Empowerment, BAZNAZ. 


\section{INTRODUCTION}

One of the problems faced by the Indonesian government or the state is poverty. The government cannot overcome or solve this problem yet. Zakat is an Islamic method of distributing income and wealth. Zakat is not merely an obligation for Muslims since it also contains the elements of human relations or habluminannas which is a very important social value. In Islam, income equality has been suggested through the Quran and the Hadith through the application of the zakat. Al-Quran explains that the allocation of zakat has been determined to whom the recipients are, however it does not explain how the zakat should be managed, whether in the form of giving consumptive money, goods or in the form of business capital. Along with the development of economic thought from experts who later gave birth to various ideas regarding the management of zakat, it can be distributed in two ways: by supporting them by giving money that can be used in a consumptive manner or by providing productive capital to be managed and developed.

Zakat is part of worship in Islam that aims to distribute and bridge the muzakki and mustahik so that the continuity of economic life between the two could be maintained. Indonesia, the largest Muslim country in the world with more than 200 million Muslims, is an important economic power. Based on the population, it can be seen that Indonesia also has a huge potential for zakat to support the economic life of the lower class people. The strategy to produce zakat is by providing capital to the community which will have a positive impact on economic development to suppress public inequality between the rich and the poor. Zakat given to the community will play a role in supporting productive economic recovery in productive activities.

Efficient zakat development can be done by establishing zakat funds as business capital to empower the needs of recipients so that the poor can continue to manage or respond to their needs. Providing zakat funds to be productive is very helpful in increasing the need for productivity, in contrast to zakat funds that focus on consumptive activities, because zakat provided to produce productive businesses can be managed permanently. If productivity continues to increase, there will be an increase in the economy gradually.

Pratama (2015), to increase proportional income, careful efforts are made in selecting the recipients of zakat in the hope that the funds will be used to prevent bad working capital returns for entrepreneurial activities. Also, to be effective in achieving the goal of increasing business independence of the mustahik, a targeted and effective program is needed where the funds can be allocated by knowing the socioeconomic conditions and the availability of their funds.

One of the community empowerment programs run by BAZNAS is the Zakat Community Development Program (ZCD). ZCD is a community development program that integrates social aspects consisting of education, health, religion, environment, and other social aspects. It presents aspects of the economy comprehensively with basic funding from zakat, infaq, and alms. BAZNAS of Lampung province has run the ZCD program in Central Lampung regency who is located in two Subdistricts namely Terbanggi Besar and Seputih Raman by distributing the zakat in the form of cattle, ducks, and goats. This program has been implemented since 2017 in hope of reducing poverty by empowering the community through the 
program. In its realization, there were 27 mustahik who received the benefits of capital in the form of livestock to be cared for and raised.

To see the extent to which this program can help uplifting the community's economy, it is necessary to have a deeper assessment of the zakat recipients in the sub-district to see whether the program has been successful or not. A quantitative assessment is needed to see the extent of the role of ZCD for the communities' economy.

\section{LITERATURE REVIEW}

Zakat Community Development (ZCD) is an activity that combines programs to solve health, education, economic, and social problems through zakat, infaq, and shodakoh. This program employs the community approach which is an organized community development method and has similar activities, a regional approach which is the geographical and location strategy as the main target of the program, and the prospect of the target area of the program relevant to the conditions of the communities, whether in urban, rural, hilly, or coastal areas.

Solihah dan Mulyadi (2018), explain that the success of zakat is very much determined from the realization of the utilization of zakat through the zakat community development (ZCD) program. In connecton with this, the problem in this study is focused on the realization of the objectives of zakat management based on Law No. 23 of 2011 through the Zakat Community Development (ZCD) program in the people of Sidanglaka Village Cianjur Regency and measures the success of the program through productive venture capital for productive zakat on people's welfare. Realization of the zakat community development (ZCD) program by providing business capital that occurred in the village of Sidanglaka as one of the areas (pilot project) BAZNAS Cianjur regency provides its own paradigm of the function of zakat for the community. The community directly gets the benefits of zakat in an effort to improve welfare.

The success rate of productive zakat revolving business capital on the walfare of the people of Sidanglaka Village Cianjur Regency, ca be measured from an increase in motile and immaterial welfare, this is indicated by an increase in average busniess income of $\mathrm{Rp} 50,000$ businesses run and in terms of immaterial understanding of the function of zakat and infaq or sodaqoh for the community receiving the program, so that the policy on theobligation of infestation determined by BAZNAS, the community carries out and almost reaches $35 \%$ is comparable to the understanding that the venture capital from zakat is equal to the term light credit.

Wijaya (2010), in a study say that highlighting the tendecy for poverty based empowerment in eradication in developing countres like Indonesia. Community empowerment in the context of community development refers to increasing community strength and authority to act to overcome their own problems. The task of the empowermnet facilitator must be developed through a learning process for the local community to build a level of independence marifests itselfin increasing the empowerment of social groups to met the basic needs of their members.

The ZCD program is based on community and village empowerment that aims to comprehensively integrate the dimensions of da'wah, economy, education, health, and social humanity, funded throuh zakat, infaq, alms, and other religious social funds. The following are the objectives of the ZCD program; (1) the realization of a society that has morals (akhlaqul karimah); (2) realization 
of strong and independent community institutions; (3) increasing the level of participation in compulsory education; (4) increase in general knowladge about health and health status through the development of a clean and healthy lifestyle; (5) increase in income and subtainable existence of community livelihood system; and (6) increasing understanding of disasterrisk reducation among communities based on local culture.

\section{RESEARCH METHODOLOGY}

\section{Type \& Nature of Research}

This research is field research which is a type of research that seeks to collect data and information about problems outside of literature. The method used is a mixed method that combines qualitative and quantitative approaches. The model used is sequential exploratory which is combining the two methods in sequence. It begins with a qualitative method and then continued by a quantitative method.

\section{Data}

\section{Primary Data}

The data in this study were obtained from interviews with relevant officials and a questionnaire filled by mustahik who became the object of research.

\section{Secondary Data}

Secondary data is the type of data obtained from company financial statements, government reports, bookkeeping in the form of principles, data in the form of notes, books and journals, as well as articles, and published research studies. The secondary data of this research were obtained from the Qur'an, Hadith, books relating to zakat management, the use of zakat, Islamic economics, and distribution of zakat, financial institutions, research methods, and more. Secondary data in this study were obtained from the Internet, especially journals, articles, official news, and others.

\section{Population \& Sample}

The population in this study consisted of 27 respondents or mustahik recipients of revolving livestock zakat from BAZNAS Lampung in Central Lampung Regency. So that, the number of samples of respondents taken in this study consisted of 27 respondents as well or the entire population in this study.

\section{Data Collecting Techniques}

\section{Observation}

The Observations in this research were done by directly observing the research location in BAZNAS Lampung to get the data needed about the recipient of zakat and to get additional data needed from the zakat fund. The researcher went to the recipient of the zakat directly.

\section{Questionnaire}

The questionnaires were given to mustahik to obtain the data on ZCD in the form of alternating livestock zakat and the incomes from their business. The measurement scale used was a Likert scale. 
Table 1. Likert Scale

\begin{tabular}{ll}
\hline \multicolumn{1}{c}{ Statements } & \multicolumn{1}{c}{ Score } \\
\hline Strongly Agree (SA) & 5 Points \\
\hline Agree (A) & 4 Points \\
\hline Neutral (N) & 3 Points \\
\hline Disagree (D) & 2 Points \\
\hline Strongly Disagree (SD) & 1 Point \\
\hline
\end{tabular}

\section{Interview}

In this study, interviews were conducted face to face with related officers who work at BAZNAS Lampung and with the mustahik in Central Lampung Regency.

\section{Documentation}

The documentation data were obtained through the documentation method. It was done by finding information from books, records, and documents from BAZNAS Lampung.

\section{Data Analysis Technique}

\section{Qualitative Data Analysis}

In this analysis technique, researchers searched for and extracted information obtained from the interviews with BAZNAS Lampung and mustahik in Central Lampung regency who received the zakat. Also, researchers gave questionnaires to mustahik to obtain valid results on a Likert scale which would then be analyzed and explained based on each indicator.

\section{Quantitative Data Analysis}

a. Validity Test

Priyatno (2011), states that item validation is used to measure the accuracy of a questionnaire or object scale, regardless of whether the questionnaire items are suitable for measuring what should be measured. It can also be done by conducting direct research using personal relationships or the corrected item-total correlation method.

b. Reliability Test

According to Priyatno (2011), reliability is a level of obstacle in a research instrument. Reliability testing is used to determine the consistency of an instrument, regardless of whether it is used repeatedly.

c. Simple Linear Regression Analysis of Economic Equation Test

In this study, simple linear regression analysis served as a statistical technique used to test the presence or absence of the influence of variable $\mathrm{X}$ on variable $\mathrm{Y}$.

Thus, it can be seen how the use of ZCD (X) has a significant impact on community empowerment (y). The formula for simple linear regression is:

$\mathrm{Y}=\mathrm{a}+\mathrm{b}(\mathrm{X})$

Description:

Y : Dependent variable (community empowerment)

a : Constant

b : Regression coefficient

$\mathrm{X}$ : Independent variable (zakat community development)

d. The t-statistics Test

Partial t-test was conducted to examine the importance of the impact of independent variables on each dependent 
variable (partial) by assuming that other variables have constants. The decision was made based on the significance value obtained which then compared to the value of $\alpha(5 \%)$ by looking at the following conditions:

If the value of $\operatorname{Sig}<\alpha$, then Ho is rejected

If the value of $\operatorname{Sig}>\alpha$, then Ho is accepted

e. The Coefficient of Determination Test $\left(\mathrm{R}^{2}\right)$

Noor (2011), the coefficient of determination (goodness of fit) is the most important indicator in regression. Determinant $\left(\mathrm{R}^{2}\right)$ indicates the ability of the dependent variable. $\mathrm{R}^{2}$ represents the effect of the ability of the variance of all the dependent variable which can be explained by the explanatory variables. A high $\mathrm{R}^{2}$ value gets a large proportion of the overall variance to be explained by the dependent variable.

\section{RESULT AND DISCUSSION}

\section{Respondents Characteristics}

Tabel 2. Respondent Characteristic

\begin{tabular}{|c|c|c|}
\hline \multicolumn{3}{|c|}{ Age of the Mustahik } \\
\hline Age & Number of Respondents & Percentage \\
\hline $25-35$ & 9 & 33.3 \\
\hline $36-45$ & 11 & 40.7 \\
\hline$>45$ & 7 & 26 \\
\hline \multicolumn{3}{|c|}{ Gender of the Mustahik } \\
\hline Gender & Number of Respondents & Percentage \\
\hline of Men & 26 & 96.3 \\
\hline Women & 1 & 3.7 \\
\hline \multicolumn{3}{|c|}{ Types of Business Owned by Mustahik } \\
\hline Livestock & Number of Respondents & Percentage \\
\hline Duck & 5 & 25.9 \\
\hline Goat & 22 & 74.1 \\
\hline \multicolumn{3}{|c|}{ Mustahik'sIncome before Receiving Zakat Funds } \\
\hline$(\mathrm{Rp})$ & Number of Respondents & Percentage \\
\hline$<1,000,000$ & 22 & 81.5 \\
\hline $1,000,000-2,000.000$ & 4 & 14.8 \\
\hline$>2,000,000$ & 1 & 3.7 \\
\hline \multicolumn{3}{|c|}{ Mustahik'sIncome after Receiving Zakat Funds } \\
\hline Income (Rp) & Number of Respondents & Percentage \\
\hline$<1,000,000$ & 22 & 81.5 \\
\hline $1,000,000-2,000,000$ & 4 & 14.8 \\
\hline$>2,000,000$ & 1 & 3.7 \\
\hline
\end{tabular}

Source : Processed Data (2020) 


\section{Validity Test}

Table 3. Validity Test

\begin{tabular}{cccccc}
\hline Variables & $\mathbf{r}_{\text {observed }}$ & $\mathbf{r}_{\text {critical }}$ & Condition & Significance & Decision \\
\hline X1 & 0,677 & 0,367 & $\mathbf{r}_{\text {observed }}>\mathbf{r}_{\text {critical }}$ & $0,000<0,05$ & Valid \\
\hline X2 & 0,498 & 0,367 & $\mathbf{r}_{\text {observed }}>\mathbf{r}_{\text {critical }}$ & $0,008<0,05$ & Valid \\
\hline X3 & 0,722 & 0,367 & $\mathbf{r}_{\text {observed }}>\mathbf{r}_{\text {critical }}$ & $0,000<0,05$ & Valid \\
\hline X4 & 0,521 & 0,367 & $\mathbf{r}_{\text {observed }}>\mathbf{r}_{\text {critical }}$ & $0,005<0,05$ & Valid \\
\hline Y1 & 0,760 & 0,367 & $\mathbf{r}_{\text {observed }}>\mathbf{r}_{\text {critical }}$ & $0,000<0,05$ & Valid \\
\hline Y2 & 0,795 & 0,367 & $\mathbf{r}_{\text {observed }}>\mathbf{r}_{\text {critical }}$ & $0,000<0,05$ & Valid \\
\hline Y3 & 0,665 & 0,367 & $\mathbf{r}_{\text {observed }}>\mathbf{r}_{\text {critical }}$ & $0,000<0,05$ & Valid \\
\hline Y4 & 0,487 & 0,367 & $\mathbf{r}_{\text {observed }}>\mathbf{r}_{\text {critical }}$ & $0,010<0,05$ & Valid \\
\hline
\end{tabular}

Source : Processed Data (2020)

The table describes the relationship the accuracy-test concludes that all indicators between each indicator that shows significant can be considered correct.

results that are $\mathbf{r}_{\text {observed }}>\mathbf{r}_{\text {critical }}$. Therefore, Reliability Test

Table 4. Reliability Test

\begin{tabular}{lcc}
\hline \multicolumn{1}{c}{ Variables } & Alpha & Description \\
\hline Zakat Community Development & 0,437 & Reliable \\
\hline Community Empowerment & 0,619 & Reliable
\end{tabular}

Source : Processed Data (2020)

From the table, it is known that the Simple Linear Regression Equation reliability test results show that all Test variables have relatively good alpha coefficients.

\section{Table 5. Simple Linier Regression Equation Test}

Coefficients $^{\mathrm{a}}$

\begin{tabular}{|c|c|c|c|c|c|c|}
\hline \multirow[b]{2}{*}{ Model } & & \multicolumn{2}{|c|}{ Unstandardized Coefficients } & \multirow{2}{*}{$\begin{array}{c}\begin{array}{c}\text { Standardized } \\
\text { Coefficients }\end{array} \\
\text { Beta }\end{array}$} & \multirow[b]{2}{*}{$\mathrm{T}$} & \multirow[b]{2}{*}{ Sig. } \\
\hline & & B & Std. Error & & & \\
\hline \multirow[t]{2}{*}{1} & (Constant) & 12.555 & 2.853 & & 4.400 & .000 \\
\hline & $\begin{array}{l}\text { Zakat } \\
\text { Community } \\
\text { Development }\end{array}$ & .304 & .181 & .318 & 1.680 & .105 \\
\hline
\end{tabular}

a. Dependent Variable: Community Empowerment

Source : Processed Data (2020) 
Based on the table it can be seen that the simple linear regression equation formed is:

$$
\mathrm{Y}=12,555+0,304 \mathrm{X}
$$

These results can be interpreted:

1. The amount of constants is 12,555 which means that if the ZCD value is 0 (zero), then the level of community empowerment's value is 12,555 .

2. Variable regression coefficient ZCD (X) is 0.304 which means that if ZCD is getting better or rising, the community empowerment (Y) will increase by $30.4 \%$.

\section{Hypothetical Test}

Based on the t-test results, it is known that $t_{\text {observed }}$ is 1,680 , and $t_{\text {critical }}$ is 2 , 0555 which means that $\mathrm{t}_{\text {observed }}<\mathrm{t}_{\text {critical }}(1,680$ $<2,0555)$ with a significance of 0.105 . This means that $0.105>0.05$, so it can be concluded that zakat community development has no significant effect on community sustainability.

\section{The Coefficient of Determination Test} (R2)

Table 6. The Coefficient of Determination Test $\left(\mathbf{R}^{\mathbf{2}}\right)$

\begin{tabular}{lcccr}
\hline \multicolumn{4}{c}{ Model Summary $^{\mathbf{b}}$} \\
\hline Model & $\mathrm{R}$ & R Square & $\begin{array}{c}\text { Adjusted R } \\
\text { Square }\end{array}$ & $\begin{array}{c}\text { Std. Error of the } \\
\text { Estimate }\end{array}$ \\
\hline 1 & $.318^{\mathrm{a}}$ & .101 & .065 & 1.169 \\
\hline $\begin{array}{l}\text { a. Predictors: (Constant), Zakat Community } \\
\text { Development }\end{array}$ \\
b. Dependent Variable: Community Empowerment
\end{tabular}

\section{Source :Processed Data (2020)}

Based on the results of the outputtable, the value of R2is 0.101 or $10.1 \%$, which means that zakat community development affects community empowerment by $10.1 \%$, while the rest (10010.1) $89.9 \%$ has no effect or is influenced by other variables not found in this study.

\section{Zakat Community Development toward Community Empowerment}

Based on the results of the conducted tests, the provision of livestock from BAZNAS Lampung does not affect community empowerment. The respondents who receive the zakat in the form of livestock had less than Rp. 1,000,000 or $81.5 \%$ of the 22 Mustahik samples. This means that BAZNAS Lampung is committed to providing zakat of livestock for communities in need. Departemen Agama Republik Indonesia (2002), the distribution of productive zakat is in line with what Allah the Almighty commanded:

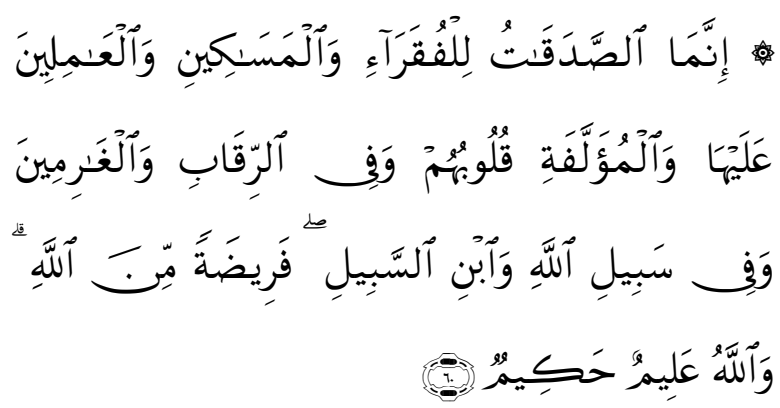

Meanings : Zakah expenditures are only for the poor and for the needy and for those employed to collect [zakah] and for bringing hearts together [for Islam] and for freeing captives [or slaves] and for those in debt and the cause of Allah and the [stranded] traveler - an obligation [imposed] by Allah. And Allah is Knowing and Wise. (QS AtTaubah: 60) 
The provision of alternating livestock zakat through the ZCD program did not affect the empowerment of mustahik. It might have been caused by other factors when the mustahik runs their businesses. However, the failure experienced by the mustahik was mainly caused by mental unpreparedness and mismanagement so that the expected target cannot be achieved.

Another factor that caused mustahik to experience difficulties in carrying out their businesses was the lack of training and knowledge provided by the BAZNAS Lampung. It made them learn on their own in developing their businesses. According to Tini,one of the mustahik who runs duck livestock, BAZNAS Lampung Province did not provide adequate training on businesses. Not only training but the controlling and monitoring by the BAZNAS Lampung were also minimum so that it did not know anything about what constraints experienced by the mustahik while running their businesses.

The mustahik desperately needs guidance from the BAZNAS Lampung in developing their business so that the zakat or capital funds provided can be truly realized for the community empowerment in the long term. Productive Zakat or livestock capital is expected to have a positive effect on mustahik so that they can be empowered and can be prosperous.

There are several indicators in the provision of productive zakat that could influence the level of income of the mustahik so that their lives can be more prosperous.

\section{Business Feasibility Study}

A business feasibility study is a stage to analyze the feasibility of a business plan to be carried out. BAZNAS Lampung, before providing funds or productive zakat capital to be given to mustahik, must conduct a business feasibility study first. This is because businesses are expected to run in the long term. However, BAZNAS Lampung did not pay attention to this, especially for mustahik recipients of ducks livestock.
BAZNAS Lampung only provided capital funds for the mustahik to buy duck seedlings which were then used as livestock without seeing whether or not the business was run by the mustahik. Not all mustahik who run duck farming has the basicability to run duck farming. It caused some difficulty to emerge in the business resulting in three out of five mustahik recipients of duck livestock had failed.

For mustahik recipients of goat livestock, BAZNAS Lampung provided capital in the form of goat seedlings which then the UPZ of Central Lampung regency of Seputih Raman District determined the mustahik who were entitled to receive the goat livestock for business.

\section{Counseling}

Counseling is intended to provide insights related to business so that the mustahik can gain knowledge about the management of zakat funds. After conducting a business feasibility study and the business has been declared as feasible, then counseling needs to be done. However, these steps were not done by the BAZNAS Lampung so mustahik had a hard time managing the business they managed. Agung states that there is no mental and management readiness of mustahik so that it might have caused the failure. There was no mental and management readiness in managing the business since BAZNAS Lampung did not conduct the counseling. The BAZNAS Lampung should guide the mustahik to provide socialization and knowledge related to the businesses that will be run.

\section{Supervision}

After the business has been run by the mustahik, supervision from BAZNAS Lampung is needed. This is intended so that the BAZNAS Lampung can provide corrections to the businesses, find out whether the funds are truly well managed, and control the development of the business. Not only that, through the supervision, but it is also expected that BAZNAS Lampung can 
find out what obstacles faced by the mustahik. This matter was not given enough attention by the BAZNAS Lampung. BAZNAS Lampung only conducted monitoring a few times and not routine, so that they did not know the obstacles faced by the mustahik. The Mustahik who received ducks were suffering because their ducks were suffering from the advance stage blue eye syndrome that cannot be cured anymore.

\section{Evaluation}

The most important thing to do is an evaluation of what has been done. This indicator aims to determine the quality or value of a program so that decisions can be taken for the next step. However, due to the lack of controlling and monitoring by BAZNAS Lampung, the evaluations of problems faced by the mustahik cannot be conducted. Consequently, there was no solution to the problems faced by mustahik that caused them to fail in their business ventures.

As in the case of empowerment, three stages cover the empowerment, they are:

\section{Awarenes stage.}

In this stage, the targets are informed that they possess the right to do something. In this case, the awareness was addressed to the mustahik who receive productive zakat. They were given enlightenment that they were entitled to a more decent life, had an adequate income to improve their standard of living and to erase the social and economic gaps in society. The mustahik was expected to be able to fulfill their needs without having to get help from others.

\section{Capacity Building Stage}

In this case, chances to obtain independence and power are given to the targets to advance. At this stage, mustahik was given the capital of self-ability by providing knowledge to be able to run a business so that they have the power to influence their lives and the lives of others.

\section{The Empowerment Stage}

This stage provides opportunities for the targets. In this stage, what is meant in providing opportunities is to provide a business capital that will be run by the mustahik. Through the provision of capital, they were expected to be able to run their business in the long run so that they can fulfill their basic economic and social needs such as self-confidence, express aspirations, and able to participate in social activities.

Islamic economics is a prototype of an economy based on Islamic values by upholding the values of togetherness in achieving prosperity. In the implementation of Islamic economics, a strong economic foundation is needed to strengthen the economy. This can be seen in the application of the 4 characteristics of the Prophet Muhammad, including:

\section{Shiddiq}

Shiddiq means truthful, in this case, what is meant by truthful is the actions or steps taken in the process of utilizing productive zakat. Based on the field, BAZNAS Lampung has been truthful in channeling productive zakat funds to the mustahik in need. However, in the implementation of the productive zakat utilization program, there were some procedures and indicators that did not get enough attention and were not carried out.

\section{Amanah}

BAZNAS Lampung has been tasked to channel the zakat funds. In the alternating livestock program through ZCD, BAZNAZ has been mandated to distribute the funds to the appropriate mustahik. However, BAZNAZ Lampung did not provide enough attention to guiding the mustahik in running their business. There were some mustahik who did not uphold the value of amanah. They considered the funds they received was just a gift given to them so that the sense of responsibility was not present. The zakat given becomes useless when the mustahik cannot manage the business they run. 


\section{Tabligh}

Tabligh means to convey where in this case, conveying the knowledge. In this program, mustahik who runs a business were not equipped with prior knowledge from the amil zakat. When they were facing obstacles, the mustahik cannot overcome them. This should be a concern for Amil Zakat to provide knowledge on how to run a business by, at least, collaborating with relevant agencies that understand the business that will be run by the mustahik.

\section{Fathonah}

Fathonah is intelligent. Intelligence is needed in managing a business so that there will be changes in life or to obtain knowledge. In this case, due to the lack of knowledge possessed, there were so many obstacles in running the business.

Based on the results of the hypothesis testing data, by looking at the income differences and analyzing the results of interviews through a questionnaire, it can be concluded that the ZCD program through the provision of alternating livestock carried out by the BAZNAS Lampung cannot empower the community in Central Lampung Regency. BAZNAS Lampung should pay more attention so that the zakat that has been given to the mustahik or the community will not be useless. It is important to assist the mustahik so that they can manage their businesses and for them to be responsible for running their businesses.

In short, do not ever forget to assist the mustahik so that they can run their business well. If the productive zakat fund which is expected to have a positive impact to eliminate the income gaps between the rich and the poor is not running well, its value will be the same as the consumptive zakat. The zakat funds are expected to provide long-term effects in the life of mustahik.

\section{CONCLUSSION}

Based on the results of SPSS data processing, it can be seen that the value of $\mathrm{t}_{\text {observed }}<\mathrm{t}_{\text {critical }} \quad(1,680<2.0555)$ with a significance value of $0.105>0.05$. Thus, it can be concluded that the alternating stock program did not affect community empowerment in Central Lampung regency. It might be caused by the fact that BAZNAS Lampung did not follow the appropriate stages in empowering the community through the zakat community development program. Also, some mustahik did not aware of the responsibility they have towards the zakat funds provided by BAZNAS Lampung.

\section{REFERENCES}

Departemen Agama Republik Indonesia. 2002. Al-Qur'an dan Terjemahannya. Fajar Mulia. Jakarta.

Noor, Juliansyah. 2011. Metodologi Penelitian: Skripsi, Tesis, Desertasi Dan Karya Ilmiah. Kencana. Jakarta.

Pratama, Yoghi Citra. 2015. Peran Zakat Dalam Penanggulangan Kemiskinan (Studi Kasus : Program Zakat Produktif Pada Badan Amil Zakat Nasional). The Journal of Tauhidinomics, 1 (1).

Priyatno, Duwi. 2011. SPSS Analisis Statistik Data Lebih Cepat Lebih Akurat. Medikom. Yogyakarta.

Solihah, Cucu \& Mulyadi, M. Budi. 2018. Realisasi Tujuan Pengelolaan Zakat Berdasarkan Undang-Undang No. 23 Tahun 2011 Melalui Program Zakat Community Development (ZCD) Pada Masyarakat Desa Sindanglaka Kabupaten Cianjur. Masalah-Masalah Hukum, Jilid 47 No. 3.

Wijaya, M. 2010. Kemiskinan Dan Pemberdayaan Masyarakat Desa. Journal of Rural and Development, 1 (1). 